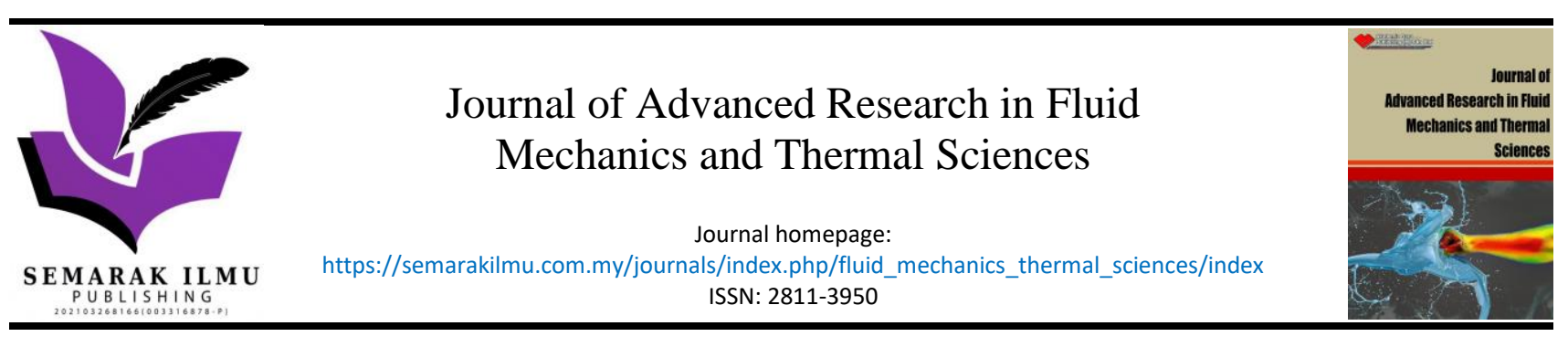

\title{
Design of Oil Water Separator for the Removal of Hydrocarbon from Stormwater Contaminated with Jet-Fuel
}

\author{
Khailash Dhasan Velautham ${ }^{1,2}$, Shreeshivadasan Chelliapan ${ }^{1,}{ }^{*}$, Samira Albati Kamaruddin ${ }^{1}$, John \\ Lawrence Meyers ${ }^{2}$ \\ Department of Engineering and Technology, Razak Faculty of Technology and Informatics, Universiti Teknologi Malaysia, 54100, Jalan Sultan \\ Yahya Petra, Kuala Lumpur, Malaysia \\ SWA Water Malaysia Sdn Bhd., D-2-2, Megan Avenue 1, 189 Jalan Tun Razak, 50400 Kuala Lumpur, Malaysia
}

\section{$\begin{array}{ll}\text { ARTICLE INFO ABSTRACT } & \text { ABST }\end{array}$}

\section{Article history:}

Received 24 July 2021

Received in revised form 7 January 2022

Accepted 9 January 2022

Available online 6 February 2022

\section{Keywords:}

Oil-Water Separator; Corrugated Plate Interceptor; Jet Fuel; Airport Storm Water; Design; Wastewater

\begin{abstract}
The airport, in general, has a huge catchment area and a hardstand area that includes runways, taxiways, as well as parking aprons. Therefore, these areas are expected to produce a huge volume of stormwater. Besides this problem, the jet fuel and suspended solids contaminate the stormwater flow rate; hence, much consideration should be given in designing the treatment system to ensure that there is no back-flow expected during the high stormwater production to avoid any flooding occurrences in the airports. Currently, the stormwater treatment system in the Malaysian airport is minimal, and there is no specific treatment for the stormwater contaminated with jet fuel in Malaysia. In this paper, an oil-water separator named Corrugated Plate Interceptor (CPI) was explored to treat stormwater contaminated with jet fuel in the airport. Treating the airport stormwater contaminated with oil, grease, or jet fuel could significantly reduce the contamination issue and develop an environmentally friendly airport in Malaysia. The CPI has combs of plates arranged in packs, and this creates the surface areas for the removal reaction of jet fuel and suspended solids between the incoming contaminated stormwater and the plates. Accordingly, in this paper, the design and development of CPI were discussed, particularly on the design criteria for the oil-water separator, standardized tank dimensions, oil storage capacity in the tank, sludge storage capacity in the tank, and finalized plate packs.
\end{abstract}

\section{Introduction}

An airport can be a significant contributor to water pollution, especially if the airport is not provided with a suitable facility to treat the airport wastes. Drainage from an airport's movement areas requires special treatment due to the contamination with oil products. Rainwater from the paved areas, especially from the apron areas, can be cleaned in a special treatment plant located at the airport through the separation of oil products or its alternative, while the collector can be connected to the local municipal treatment plant [1-2]. Furthermore, the dangerous areas of the

\footnotetext{
* Corresponding author.

E-mail address: shreeshivadasan.kl@utm.my
}

https://doi.org/10.37934/arfmts.92.1.162176 
airport, such as the fuel storage, aircraft hangars, in addition to the aircraft and ground service equipment maintenance facilities, need to be equipped with special traps for oil products, and these should be inspected regularly [3]. Many airport facilities experience the issue of stormwater contaminated with oils. Most of this contamination comes from leaking jet fuel tank and spills associated with airport fueling stations, airport storage tanks, and airport vehicle maintenance operations [4]. The rainwater mixing with oils is collected in the containment basins and often contains small hydrocarbons. Therefore, it is necessary to remove the oils contaminants from the water before it may be discharged from the airport facility.

There are many types of oil water separators being used in airports from all over the world. However, as the environmental regulation of oils in water discharges is increasing and becoming more stringent, the airport oil-water separators specification and design are also becoming increasingly more complicated. The possible applications for coalescing plate separators functioning as airport oil-water separators include fuel farm stormwater, fueling trucks, fueling aprons, and vehicle maintenance operations [5]. For fuel farm stormwater and fueling aprons, the oil-water separators must be able to treat contaminated water before discharged into surface waters.

The methods to remove oils from water are ranging from very simple tanks to very elaborate membrane technology-based systems. Oil-water separation methods mainly include gravity separation, centrifugal separation, electric dehydration separation, chemical processing, and coalescence separation ([5-7]. Centrifugal and electrical dehydration separation processes require additional equipment that would increase energy consumption. Meanwhile, the chemical treatment method depends on chemical agents that can easily cause secondary pollution and have a higher cost due to the related equipment needed. The corrugated plate oil-water separation technology is the organic combination of gravity and coalescence separation methods. This technology has become a hot spot for researchers and also for many companies due to its feasibility, low operating cost, and effectiveness [8]. Unfortunately, the research on experimental microscopic and mechanisms relating to corrugated plate packs applied in oil-water separation treatment is insufficient, and the lack of data strongly hindered the further optimization of the technology.

A Corrugated Plate Separator (CPS) is the most effective separation and treatment technology used so far in separating the oils from water. The application of corrugated plate packs for oil-water separation was originated and developed by the American Petroleum Institute (API) [9]. The separation tank can be categorized as a gravity oil-water separation device, and it has many advantages, including having a simple structure, easy maintainability, and high oil removal efficiency. The corrugated plates provide tortuous channels for the fluids to flow back and forth. Hence, this action subsequently optimizes the coalescence of the dispersed droplets. There are many types of corrugated plate packs, such as Parallel Plate Interceptor (PPI), Coalescence Plate Separator (CPS), and the Corrugated Plate Interceptor (CPI), and the design modifications of plate packs that had been developed since 1950 [9-12]. Situated at the heart of the CPS, the CPI minimizes the rising distance of the oil droplet before it comes into contact with other oil droplets. Although the PPI separator is an important improvement in separating the oils from water, the efficiency is lower. Thus, the CPI was jointly developed by two Shell's engineers named Jan Cornelissen and Jacob Pielkenrood during their search for the optimal oil-water separation system [13]. This CPI is utilized in most of the industries to date. Basically, CPI is an advanced version of PPI where the plates are placed in the basin at a certain angle (normally 45o) of inclination that allows the oils to rise along with the lower parts of the plates and to coagulate to become larger droplets via corrugation peak. Many factors, such as flow field, initial oil concentration, structural parameters such as length, oil-water separation efficiency, plate spacing, and surface properties of materials, are affecting the separation efficiency of CPI. 
Many techniques are available for the removal of oil of the produced water to meet the discharge requirements which can be categorized as; gravity or coalescence separators, electrical, mechanical separators and chemical separators [8]. From all these techniques CPI oil separators are the most practical and economic in terms of the initial and operating costs and the wide range of operating conditions [8]. Electrical or mechanical separators require the use of extra power while chemical separation techniques necessitate the use of a subsequent separation process to separate the used chemicals.

Several other studies were focused on enhancing the separation efficiency by proper modification of the chemical or physical properties of the separator plates or the filtration or separation media [14-16]. However, the performance of such techniques deteriorates rapidly with operation and in some cases their usage is not beneficial at all [8]. Despite its wide use, available research literature on CPI does not allow the full use of its advantages especially its compact design in comparison to other gravity separators like the American Petroleum Institute (API) separation tanks [17]. Most of the research is concerned with the performance of available CPI units for different operating conditions [18-20].

The aim of this study is to design and develop a CPI for the treatment of stormwater contaminated with jet fuel in an airport. The more specific objectives of this study are to evaluate the finalized design of the CPI in terms of laminar flow, storage volume of the sludge, storage volume of the separated jet fuel for the given flowrates, inlet, and outlet velocities, and finalized plate pack design. The treatment of stormwater contaminated with oil in Malaysian airport is quite minimal, or not reported. This study is significant since it explored an additional essential contaminant treatment in stormwater which is jet fuel. The use of CPI as oil water separator is the most practical and economic method which can remove oil from airport stormwater. Therefore, treating the airport stormwater which is contaminated with the jet fuel could significantly reduce the stormwater contamination for a better environment in Malaysia.

\section{Methodology}

\subsection{Experimental Design}

The design of the CPI was based primarily on the BSEN858-1 \& 2 and API421 [21-23], and other standards such as Petronas and Shell, including other manufacturers recommendations. Most of the $\mathrm{CPI}$ are either designed to comply to BSEN858-1 \& 2 or to API421. However, in this study, the CPI was designed based on the guideline stipulated and comply with both API421 and BSEN858-1 \& 2 standards. The reasons for combining the BSEN858-1 \& 2 and API421 standards is because the developed CPI must comply with many design requirements for the airport development. There are several design requirements which are merely specifically in either one of these standards. For example, the BSEN858- $1 \& 2$ has explicitly specifies having oil stop valve or shut off valves for the purpose of curbing the accidental discharge, which have not spelled out in the API421.

The design flow rate included the possibility of having a bypass line during a heavy or huge storm, especially in countries like Malaysia with high rainfall intensity. This is an important criterion as the preliminary rainfall intensity data showed that this CPI is probably and potentially the largest CPI in the world. This large flow rate was handled using the flow regulators installed upstream to the oilwater separators to ensure that the stormwater runoff was drained from the pavement as soon as possible and was collected in an adequate drainage system.

The BSEN 858 has more stringent design criteria that clearly mentioned that the effluent of 5 $\mathrm{mg} / \mathrm{l}$ should be met [21-23]. This target set by the BSEN858-1 \& 2 is higher than the API421 and the limit set by the Malaysia Environmental Quality Act, 1974 Environmental Quality (Sewage and 
Industrial Effluents) Regulations of 1979 [24], in accordance with the standard B which is $10 \mathrm{mg} / \mathrm{l}$. Moreover, the testing procedures and the laboratory analysis were quite detailed, and the volume storage capacity of the separated oil was quite well defined.

While the BSEN858-1 \& 2 standard focuses on the overall specification of the oil-water separator system and is mostly suitable for all the related applications with the above advantages, there are still many important parameters required to follow or refer from the API421 standard. One example is the design development of these CPI types, especially in the detailed design of the plate packs. The oil droplet sizes is one of the important parameters that are referring to API421, as this API421 uses the oil droplet sizes to determine the most suitable treatment of the oily stormwater by using the $\mathrm{CPI}$, instead of by using the Cyclone separator, centrifuge or API separator. Other parameters are the plate angle that influences the efficiency of the new CPI, the plate spacing since the fouling influences the efficiency of the new CPI's, and the flow requirements like laminar or turbulent based on the Reynolds numbers. The experimental flow chart of this study is illustrated in Figure 1.

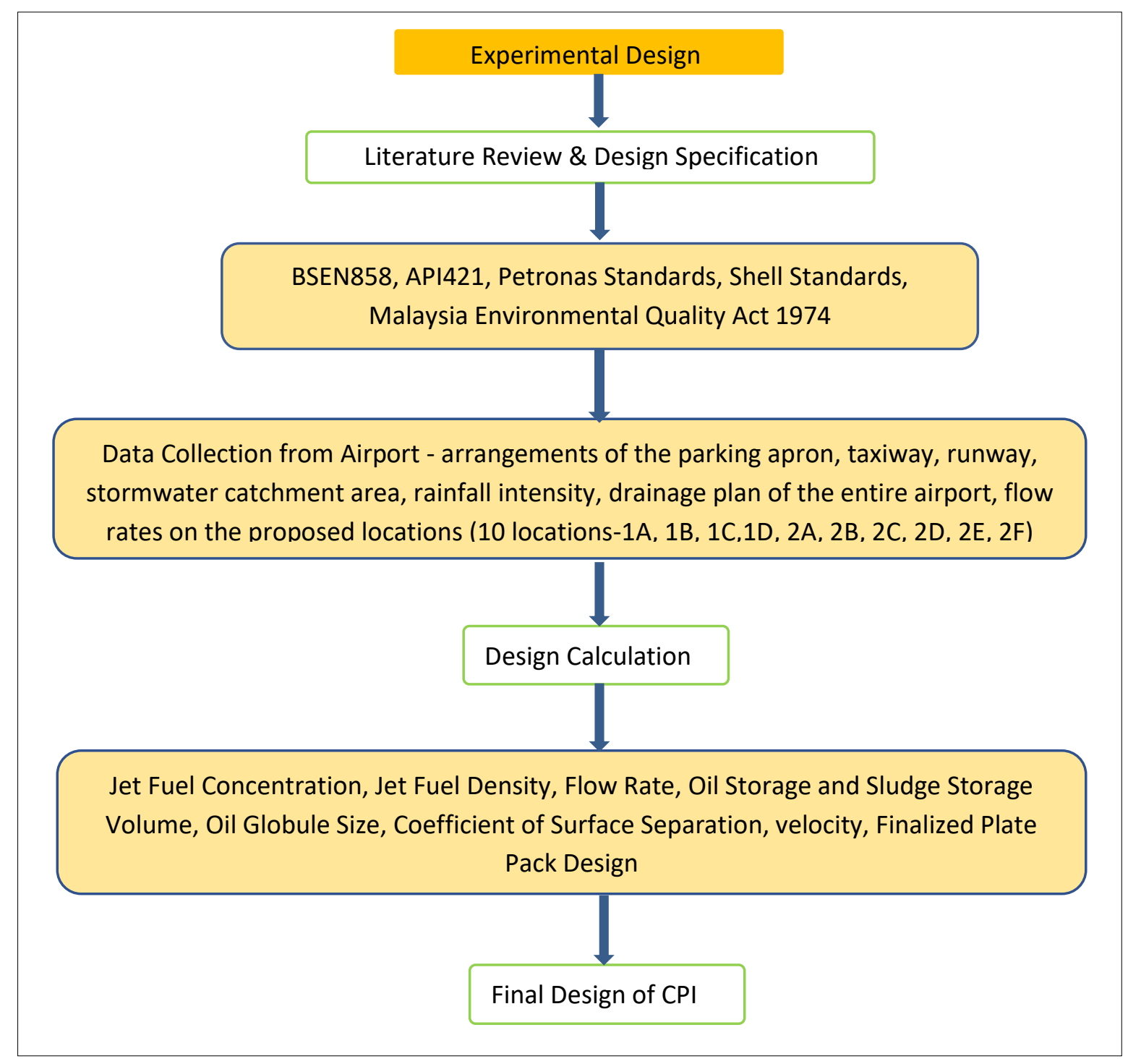

Fig. 1. Experimental flow chart of the study 


\subsection{Data Collection from the Airport}

The data collecting activity from the airport is the most challenging task in the process of developing the CPI. From the data gathered, the general arrangement of the existing drainage system in the airport was divided into 10 areas. With the concept of effluent management at source, the CPI was located downstream of the primary drainage system and upstream of the secondary drainage system. The 10 areas were further divided into 2 separate sections. Section 1 consist of area $1 A, 1 B$, $1 C$ and 1D and Section 2 consist of area 2A, 2B, 2C, 2D, 2E and 2F. Typically, it is within the first 20 minutes of the storm, the jet fuel or oil is carried over to the CPI for the separation process. This is called the first flush theory in the stormwater management and it is generally referred as first flush. Consequently, the flow rate was taken based on 3 months Average Recurrence Interval (ARI) rainfall intensity of $50 \mathrm{~mm} / \mathrm{hr}$, and this design flow rate is more than sufficient and can be classified as the peak flow rate. In the design calculations, the flow rates were calculated based on BSEN858-1 standard.

\subsection{Sludge Storage Volume}

The sludge storage volume can be determined with a series of formula specified in BSEN 585-2. For airport which has a road tarmac and parking apron the sludge expected to flow in the stormwater is very small less than $50 \mathrm{mg} / \mathrm{l}$, hence it falls under the category; small processing wastewater with defined small sludge volume or all rainwater collecting areas where a small amount of silt from traffic or similar appears, i.e., catchment basins on petrol tank areas and covered filling stations. The following formula was used to calculate sludge storage volume:

$V s=100 \times N S / f_{d}$

where Vs is the volume of sludge storage $(\mathrm{m} 3)$, NS is the fow rate $(\mathrm{l} / \mathrm{s})$, and $\mathrm{f}_{d}$ is the density factor which is equivalent to 1 for liquid/fuel which has the density 0.85 or below. As a result, $V s$ is equal to 100 litres for every litre per second $(100 \mathrm{l} / \mathrm{l} / \mathrm{s})$.

\subsection{Oil Storage Volume}

The oil storage volume was calculated in 2 parts; oil volume 1 (V1) and oil volume 2 (V2), where V1 is the oil storage volume in the inlet zone preceding the first plate pack and V2 is the oil storage volume in the vicinity of the plate packs. The oil storage volume is the total of $V 1+V 2$, which occupies space above the base of the top plate pack comb. The oil storage volumes were determined for each size of oil separator as follows:

$V 1=L[(r 2) *(\cos -1(r-h) / r)]-[(r-h) * \operatorname{sqrt}(2 r h-h 2)]$

$V 2=L[(r 2) *(\cos -1(r-h) / r)]-[(r-h) * \operatorname{sqrt}(2 r h-h 2)] \times 0.75$

where $r$ is the radius of the tank $(m), L$ is the length $(m)$, and $h$ is the height of the tank $(m)$. 


\section{Results}

\subsection{Design Criteria for Oil Water Separator}

The selected design criteria are as summarized in Table 1 below. These design criteria are important, thus must be finalized first before the other details and designing factors are analyzed. The dimensions of CPIs were found to be limited to the available spaces or areas in the airports, especially in terms of length, width, depth, including the inlet and connections to the primary and secondary drainage, respectively. On the other hand, stringent criteria were observed (according to the design criteria listed in Table 1) and were incorporated into the design. Therefore, due to these constraints, the tank sizes of the CPIs were limited to a maximum diameter of $3.2 \mathrm{~m}$ and a length of below $13.5 \mathrm{~m}$ in order to accommodate the flow equalization chambers or the sludge collection sumps preceding the tanks. Most importantly, the dimensions of the proposed CPI tanks should be able to contain the $10 \mathrm{l} / \mathrm{I} / \mathrm{s}$ oils and $50 \mathrm{l} / \mathrm{l} / \mathrm{s}$ sludge storage capacities, respectively. The maximum proposed diameter of $3.2 \mathrm{~m}$ and length of $13.5 \mathrm{~m}$ was appropriate and within the allowable dimensions; therefore, they can be transported easily into the airports through the use of normal heavy vehicles like low loader trucks. Although the maximum diameter and the maximum length were proposed, the sizes were kept standardized and as uniform as possible to ease the fabrication and manufacturing processes. Hence, four numbers of standards and uniform dimensions were successfully established according to the considerations given and based on the above-mentioned constraints. The standards that follow the proposed uniform sizes and dimensions are as shown in Table 2. Then, the proposed standards with the respective diameter and the length of the CPI tanks sizes were then fitted accordingly into the respective areas, based on the requirements, such as flow rates and volumes, as shown in Table 3.

Table 1

The design criteria summary

\begin{tabular}{ll}
\hline Design criteria & Value \\
\hline Influent hydrocarbons & $4,250 \mathrm{ppm}$ (BSEN858) \\
Oil Specific Gravity & 0.85 \\
Treated effluent quality & $5 \mathrm{ppm}$ \\
Oil storage volume & $10 \mathrm{I} / \mathrm{l} / \mathrm{s}$ \\
Oil Globule Size & $130 \mu \mathrm{m}$ \\
Coefficient of surface separation & $0.72 \mathrm{~m}^{2} / \mathrm{l} / \mathrm{s}$ \\
Surface charge & $5 \mathrm{~m} / \mathrm{h}$ \\
Sludge storage volume in CPI & $50 \mathrm{I} / \mathrm{l} / \mathrm{s}$ \\
Sludge storage volume in SCS & $50 \mathrm{I} / \mathrm{l} / \mathrm{s}$ \\
Influent temperature: & $20^{\circ} \mathrm{C}$ \\
Plate Pack Material of Construction & Stainless Stee \\
Plate Pack Material Configuration & Corrugated Plates \\
Plate Pack Inclination/ Angle & $45^{\circ}$ \\
Flow Direction & Cross Flow \\
Plate Spacing & $10 \mathrm{~mm}$ \\
\hline
\end{tabular}

Table 2

Standardized tank dimensions of the CPI

\begin{tabular}{lll}
\hline No. & Tank Diameter $(\mathrm{m})$ & Tank Length $(\mathrm{m})$ \\
\hline Standard 1 & 2.8 & 10 \\
Standard 2 & 2.8 & 12 \\
Standard 3 & 3.0 & 12 \\
Standard 4 & 3.2 & 13.5 \\
\hline
\end{tabular}


Table 3 shows clearly the proposed dimensions of the tanks, and the respective volumes for each area were well within the required oil and sludge storage volume capacities, as mentioned previously in Table 1 . The last column in Table 3 shows the remaining sludge storage capacity of $50 \mathrm{l} / \mathrm{l} / \mathrm{s}$ contained within the sludge collection sump. For maintenance and desludging purposes, the circular manholes were proposed to be built with a diameter of $900 \mathrm{~mm}$ at the sludge chamber within the $\mathrm{CPI}$ tanks and with the manholes of $900 \mathrm{~mm} \times 900 \mathrm{~mm}$ at the sludge collections sumps. Furthermore, the inlet flow baffles were designed to be fitted at both inlet sludge collection sumps and CPI tanks to direct the flow downwards and enhance the dropping and settlements of solids as much as possible at the allocated sludge collection areas.

Table 3

Proposed tank dimensions of the CPI

\begin{tabular}{|c|c|c|c|c|c|c|c|c|c|c|c|}
\hline No. & Area & $\begin{array}{l}\text { Flow } \\
\text { rate } \\
\left(\mathrm{m}^{3} / \mathrm{h}\right)\end{array}$ & $\begin{array}{l}\text { Flow } \\
\text { rate } \\
(\mathrm{I} / \mathrm{s})\end{array}$ & $\begin{array}{l}\text { No of } \\
\text { OWS } \\
\text { Tank }\end{array}$ & $\begin{array}{l}\text { Flow } \\
\text { rate } \\
@ \\
\text { each } \\
\mathrm{CPI} \\
(\mathrm{I} / \mathrm{s})\end{array}$ & $\begin{array}{l}\text { Tank } \\
\text { diam. } \\
\text { (m) }\end{array}$ & $\begin{array}{l}\text { Tank } \\
\text { length (tan } \\
-\tan )(\mathrm{m})\end{array}$ & $\begin{array}{l}\text { Total } \\
\text { volume } \\
\text { of each } \\
\text { tank } \\
\left(\mathrm{m}^{3}\right)\end{array}$ & $\begin{array}{l}\text { Oil } \\
\text { storage } \\
\text { required } \\
\text { in } 10 \mathrm{I} / \mathrm{I} / \mathrm{s} \\
@ \text { each } \\
\mathrm{CPI} \\
\left(\mathrm{m}^{3}\right) \\
\end{array}$ & $\begin{array}{l}\text { Sludge } \\
\text { storage } \\
\text { required } \\
\text { in } 50 \mathrm{I} / \mathrm{I} / \mathrm{s} \\
@ \text { each } \\
\mathrm{CPI} \\
\left(\mathrm{m}^{3}\right)\end{array}$ & $\begin{array}{l}\text { Sludge } \\
\text { storage } \\
\text { required } \\
\text { in } 50 \mathrm{l} / \mathrm{l} / \mathrm{s} \\
@ \text { each } \\
\mathrm{SCS} \\
\left(\mathrm{m}^{3}\right)\end{array}$ \\
\hline 1 & $1 \mathrm{~A}$ & 5,868 & 1,630 & 2 & 815 & 2.8 & 12.0 & 73.89 & 8.15 & 40.75 & 40.75 \\
\hline 2 & $1 \mathrm{~B}$ & 5,508 & 1,530 & 2 & 765 & 2.8 & 12.0 & 73.89 & 7.65 & 38.25 & 38.25 \\
\hline 3 & $1 \mathrm{C}$ & 9,828 & 2,730 & 2 & 1,365 & 3.2 & 13.5 & 108.57 & 13.65 & 68.25 & 68.25 \\
\hline 4 & $1 \mathrm{D}$ & 7,740 & 2,150 & 2 & 1,075 & 3.0 & 12.0 & 84.82 & 10.75 & 53.75 & 53.75 \\
\hline 5 & $2 \mathrm{~A}$ & 6,480 & 1,800 & 2 & 900 & 3.0 & 12.0 & 84.82 & 9.00 & 45.00 & 45.00 \\
\hline 6 & $2 B$ & 3.024 & 840 & 1 & 840 & 2.8 & 12.0 & 73.89 & 8.40 & 42.00 & 42.00 \\
\hline 7 & $2 \mathrm{C}$ & 7,380 & 2,050 & 2 & 1,025 & 3.0 & 12.0 & 84.82 & 10.25 & 51.25 & 51.25 \\
\hline 8 & $2 \mathrm{D}$ & 9,900 & 2,750 & 2 & 1,375 & 3.2 & 13.5 & 108.57 & 13.75 & 68.75 & 68.75 \\
\hline 9 & $2 \mathrm{E}$ & 7,920 & 2,200 & 2 & 1,100 & 3.2 & 13.5 & 108.57 & 11.00 & 55.00 & 55.00 \\
\hline 10 & $2 \mathrm{~F}$ & 1,368 & 380 & 1 & 380 & 2.8 & 10.0 & 61.58 & 3.8 & 19.00 & 19.00 \\
\hline
\end{tabular}

Since the tank size was determined previously, so the inlet and outlet pipes were also carefully selected to ensure the appropriate velocity of the water flow. The velocity of flow through the pipeline is also another matter of consideration during the pipeline design process. If the velocity is too great, the suspended particles in the flow can cause excessive erosion of the pipe. In contrast, if the velocity is too low, these suspended particles may settle out of the flow and collect at low points in the pipeline, eventually clogging the pipe if left unattended. The recommended water velocity in the pipes should be below $2.5 \mathrm{~m} / \mathrm{s}$ and above $0.7 \mathrm{~m} / \mathrm{s}$. The maximum allowable velocity is $3 \mathrm{~m} / \mathrm{s}$, and the minimum is $0.5 \mathrm{~m} / \mathrm{s}$. The findings showed that all the proposed inlet and outlet pipe sizes, based on the calculations, were well within the maximum and minimum limits of the mentioned velocities, as shown in Table 4. 
Table Error! No text of specified style in document. CPI tanks inlets and outlets with the corresponding velocities

\begin{tabular}{llllllllllll}
\hline No. & Area & Ref. & $\begin{array}{l}\text { Flow rate } \\
\left(\mathrm{m}^{3} / \mathrm{h}\right)\end{array}$ & $\begin{array}{l}\text { Drain } \\
\text { pipe } \\
\text { dia. } \\
(\mathrm{mm})\end{array}$ & $\begin{array}{l}\text { No of } \\
\text { OWS } \\
\text { Tank }\end{array}$ & $\begin{array}{l}\text { Tank } \\
\text { Inlet } \\
(\mathrm{mm})\end{array}$ & $\begin{array}{l}\text { Inlet } \\
\text { Area } \\
\left(\mathrm{m}^{2}\right)\end{array}$ & $\begin{array}{l}\text { Inlet } \\
\text { Velocity } \\
(\mathrm{m} / \mathrm{s})\end{array}$ & $\begin{array}{l}\text { Tank } \\
\text { Outlet } \\
(\mathrm{mm})\end{array}$ & $\begin{array}{l}\text { Outlet } \\
\text { Area } \\
\left(\mathrm{m}^{2}\right)\end{array}$ & $\begin{array}{l}\text { Outlet } \\
\text { Velocity } \\
(\mathrm{m} / \mathrm{s})\end{array}$ \\
\hline 1 & 1 A & R6 & 5,868 & 1800 & 2 & 700 & 0.385 & 2.12 & 800 & 0.503 & 1.62 \\
2 & 1 B & T7 & 5,508 & 1800 & 2 & 650 & 0.332 & 2.31 & 750 & 0.442 & 1.72 \\
3 & 1 C & V7 & 9,828 & 2100 & 2 & 800 & 0.503 & 2.72 & 900 & 0.636 & 2.15 \\
4 & 1 D & Y6 & 7,740 & 2100 & 2 & 750 & 0.442 & 2.43 & 900 & 0.636 & 1.69 \\
5 & 2 A & A6 & 6,480 & 1800 & 2 & 700 & 0.385 & 2.34 & 800 & 0.503 & 1.79 \\
6 & 2 B & RR2 & 3.024 & 900 & 1 & 650 & 0.332 & 2.53 & 750 & 0.442 & 1.90 \\
7 & 2 C & D9 & 7,380 & 1800 & 2 & 750 & 0.442 & 2.32 & 900 & 0.636 & 1.61 \\
8 & 2 D & F7 & 9,900 & 2100 & 2 & 850 & 0.568 & 2.42 & 950 & 0.709 & 1.94 \\
9 & 2 E & I8 & 7,920 & 1800 & 2 & 750 & 0.442 & 2.49 & 900 & 0.636 & 1.73 \\
10 & 2 F & I11 & 1,368 & 1200 & 1 & 500 & 0.196 & 1.94 & 600 & 0.283 & 1.34 \\
\hline
\end{tabular}

\subsection{Oil Storage Capacity in the Tank}

Figure 2 shows the plan view of the oil storage area within the CPI tanks from the tank inlet to the outlet side of the plate packs. Meanwhile, Figure 3 shows the Elevation View with the space portion higher than the plate packs. The oil storage volume was calculated in 2 parts of oil volume 1 (V1) \& oil volume 2 (V2), where the V1 is referring to the oil storage volume in the inlet zone preceding the first plate pack, while the $\mathrm{V} 2$ is referring to the oil storage volume in the vicinity of the plate packs. The oil storage volume is the summation of V1 + V2 and is the space above the top plate pack comb base. Based on Figure 2, the total oil storage volumes were calculated for the 4 proposed and standardized sizes of the CPI tanks. The total oil storage volumes for these sizes are as summarized in Table 5 below.

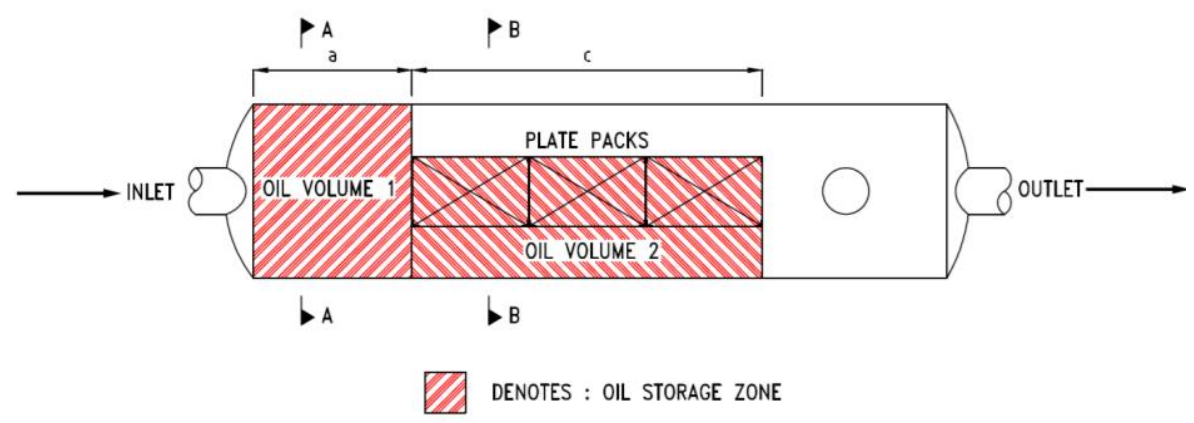

Fig. 2. Plan view of the oil storage in the Tank 


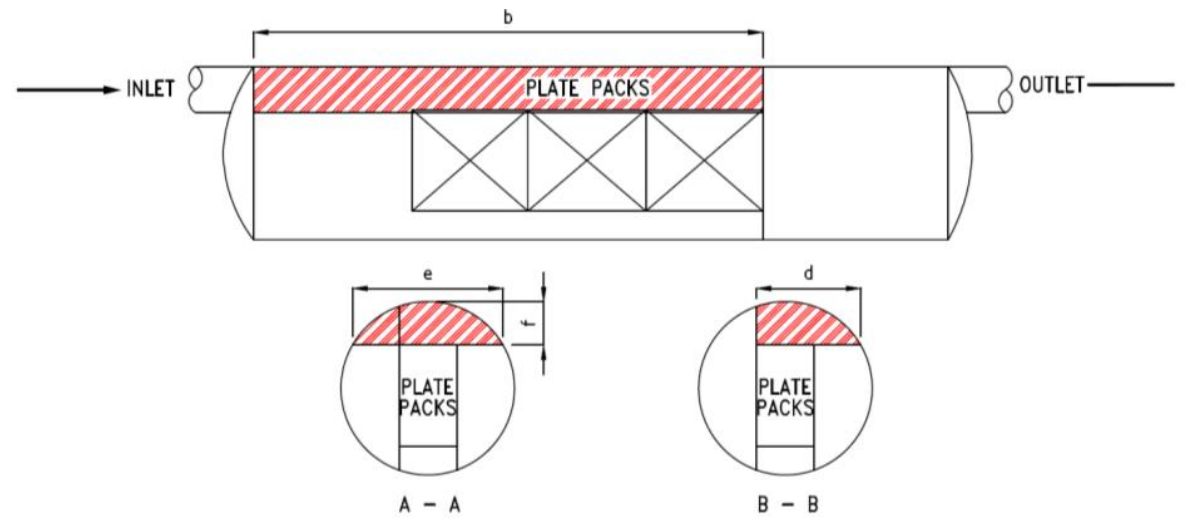

Fig. 3. Elevation view of the oil storage in the tank

Table 5

Total oil storage volume in proposed cpi tank sizes

\begin{tabular}{lllllllllll}
\hline No. & $\begin{array}{l}\text { Tank } \\
\text { Diam } \\
(\mathrm{m})\end{array}$ & $\begin{array}{l}\text { Tank } \\
\text { Length } \\
(\mathrm{m})\end{array}$ & $\begin{array}{l}\mathrm{a} \\
\text { Length } \\
\text { for V1 } \\
(\mathrm{m})\end{array}$ & $\begin{array}{l}\text { bength } \\
\text { for V2 } \\
(\mathrm{m})\end{array}$ & $\begin{array}{l}\mathrm{d} \\
(\mathrm{m})\end{array}$ & $\begin{array}{l}\mathrm{e} \\
(\mathrm{m})\end{array}$ & $\begin{array}{l}\mathrm{f} \\
\text { Height } \\
\text { for V1 } \\
\text { and } \\
\mathrm{V} 2, \\
(\mathrm{~m})\end{array}$ & $\begin{array}{l}\mathrm{V} 1, \\
\left(\mathrm{~m}^{3}\right)\end{array}$ & $\begin{array}{l}\mathrm{V} 2, \\
\left(\mathrm{~m}^{3}\right)\end{array}$ & $\begin{array}{l}\mathrm{Vt}, \\
\left(\mathrm{m}^{3}\right)\end{array}$ \\
\hline 1 & 2.8 & 10 & 3.70 & 4.42 & 1.485 & 2.090 & 0.48 & 2.599 & 2.329 & 4.928 \\
2 & 2.8 & 12 & 3.70 & 6.7 & 1.485 & 2.206 & 0.60 & 3.579 & 4.861 & 8.441 \\
3 & 3.0 & 12 & 3.70 & 6.7 & 1.54 & 2.614 & 0.75 & 5.113 & 6.944 & 12.057 \\
4 & 3.2 & 13.5 & 3.00 & 8.84 & 1.70 & 2.770 & 0.85 & 5.136 & 11.352 & 16.488 \\
\hline
\end{tabular}

\subsection{Sludge Storage Capacity in the Tank}

The available sludge storage capacity within the CPI tanks was directly calculated by subtracting the oil volume from the volume of the total tank. Although this scenario can only happen when the tanks are entirely filled with sludge (due to the lack of desludging or maintenance works being carried out) and therefore, no stormwater is able to flow through, but the calculated available volume is able to signify the sludge storage capacity in the CPI tanks (Table 6).

Table 6

Actual available sludge storage volume in proposed cpi tank sizes

\begin{tabular}{llllll}
\hline No. & $\begin{array}{l}\text { CPI Tank } \\
\text { Diam. }(\mathrm{m})\end{array}$ & $\begin{array}{l}\text { CPI Tank } \\
\text { Length }(\mathrm{m})\end{array}$ & $\begin{array}{l}\text { Total volume of } \\
\text { @ each CPI } \\
\text { Tank }\left(\mathrm{m}^{3}\right)\end{array}$ & $\begin{array}{l}\text { Actual oil storage } \\
\text { vol. @ each CPI Tank } \\
\left(\mathrm{m}^{3}\right)\end{array}$ & $\begin{array}{l}\text { Actual Available sludge } \\
\text { storage vol. @ each CPI } \\
\text { Tank }\left(\mathrm{m}^{3}\right)\end{array}$ \\
\hline 1 & 2.8 & 10 & 61.58 & 4.928 & 56.652 \\
2 & 2.8 & 12 & 73.89 & 8.441 & 65.449 \\
3 & 3.0 & 12 & 84.82 & 12.057 & 72.762 \\
4 & 3.2 & 13.5 & 108.57 & 16.488 & 92.082 \\
\hline
\end{tabular}

\subsection{Finalised Plate Pack Design}

The design of plate packs essential for the performance of CPI was provided in this paper. Although the CPI tank dimensions, inlet pipe works, outlet pipe works, the flow equalization chamber or sludge collection sumps may differ for each and every specific area, as well as according to the allocated space, the design model of the plate packs was meant to be same and identical to all the 10 areas tested. This is an additional advantage feature that is required to enable and to ensure that 
the retrofitting works can be carried out easily at any one of the 10 areas, especially in the future, without any needs for re-engineering works. However, the design must comprise the quantity of the plate packs that need to be engineered and identified according to the respective flow rate in each of these 10 areas.

The design was based on a rigid cuboid stainless steel frame that is housing the plate pack sheets. The dimensions of this cuboid were carefully selected and must be small enough to fit within the smallest proposed and standardized dimensions of the CPI tanks. At the same time, these dimensions were finalized after considering the occurrences of cross-flow, oil storage allocations at the top and sludge storage allocation at the bottom. The plate sheets were preferably made of stainless steel and corrugated. The sheets were designed to arrange to allow the stormwater to flow from a cross-flow direction and at a plate angle of $45^{\circ}$. In addition, the plate sheets were spaced at $10 \mathrm{~mm}$. These designs and arrangements are as illustrated in Figure 4 below for easy understanding. Figure 4 also shows the flow paths of water, oil, and solids quite clearly. Based on the finalized dimensions of the plate packs, the corresponding design calculations are as shown in Table 7.

\begin{tabular}{ll}
$\begin{array}{l}\text { Table } 7 \\
\text { Design calculation of the plate packs }\end{array}$ \\
\hline Design & Value \\
\hline Length of each Pack & \\
Outside frame: & $2.0 \mathrm{~m}$ \\
Inside frame: & $1.9 \mathrm{~m}$ \\
Width & $1.2 \mathrm{~m}$ \\
Height: & \\
Outside frame: & $2.0 \mathrm{~m}$ \\
Inside frame: & $1.9 \mathrm{~m}$ \\
Plate spacing: & $10 \mathrm{~mm}$ \\
Plate angle: & $45^{\circ}$ \\
Total plate area per pack, Aa: & $433.2 \mathrm{~m}{ }^{2}$ \\
(Aa = average plate length $\times$ plate width $\times$ No of plate & \\
pack sheets = 1.9 $1.2 \times 1900 / 10)$ & \\
Effective surface area, As: & $306.3 \mathrm{~m}^{2}(\mathrm{As}=\mathrm{Aa} / \mathrm{V} 2)$ \\
& due to $\mathrm{plate}$ angle $=45^{\circ}$ \\
Design Rise velocity, $\mathrm{Vr}:$ & $5.0 \mathrm{~m} / \mathrm{h}$ \\
Design flow rate per pack: $\mathrm{Q}=$ As $\times \mathrm{Vr}$ & $1,531.5 \mathrm{~m}^{3} / \mathrm{h}(425.42 \mathrm{l} / \mathrm{s})$ \\
\hline
\end{tabular}

Based on the above, the analysis of the computation and the required actual surface area for each respective area were carried out by comparing the differences between the minimum and the optimum plate packs quantities. In other words, the differences between the minimum and optimum quantities were determined to gauge the designed dimension of the plate pack that can be additionally fitted into the CPI's tanks dimensions. The minimum required plate pack quantities are easily computed, as shown in Table 8. Meanwhile, the optimum plate pack quantities that can be additionally fitted into the dimensions of the proposed tank are as shown in Table 9. The minimum plate packs quantities are 51, and the optimum quantities are 59. The difference between the minimum and optimum plate pack quantities was only 8 . However, a substantial performance increased was observed when the optimum plate pack quantities were chosen. 


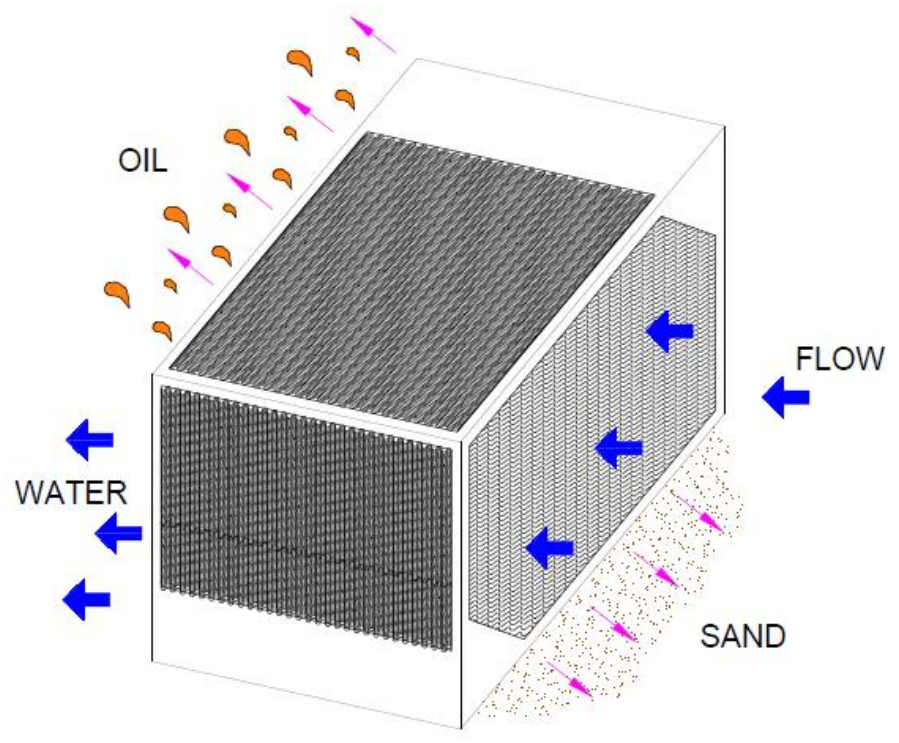

OIL REMOVAL

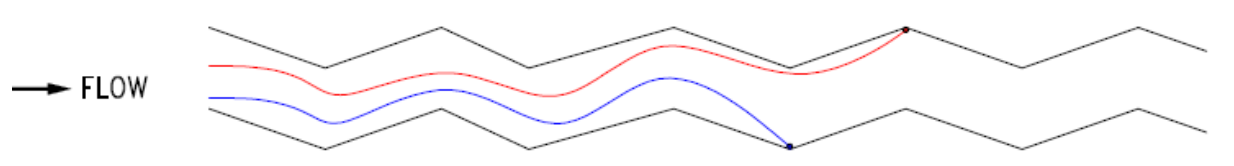

OIL DROPLETS RISE TO THE UNDER SIDE OF A PLATE PACK SHEET

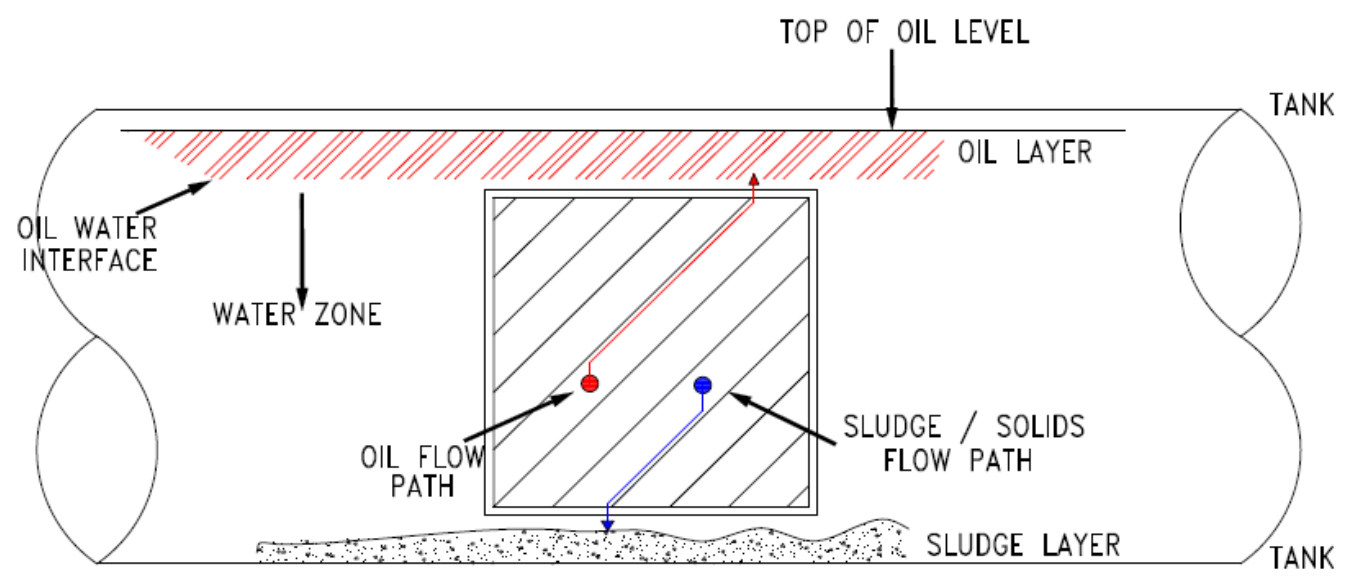

Fig. 4. Crossflow direction, the path of the oil globules and solid particles tank 


\section{Table 8}

The minimum required quantity of plate packs

\begin{tabular}{lllllllllll}
\hline No & Area & Ref. & $\begin{array}{l}\text { Flow rate } \\
\left(\mathrm{m}^{3} / \mathrm{h}\right)\end{array}$ & $\begin{array}{l}\text { No } \\
\text { of } \\
\text { CPI }\end{array}$ & $\begin{array}{l}\text { Flow } \\
\text { rate @ } \\
\text { each } \\
\text { CPI } \\
\left(\mathrm{m}^{3} / \mathrm{h}\right)\end{array}$ & $\begin{array}{l}\text { Surface } \\
\text { area } \\
\text { required } \\
\left(\mathrm{m}^{2}\right)\end{array}$ & $\begin{array}{l}\text { Plate } \\
\text { Pack } \\
\text { Surface } \\
\text { area }\left(\mathrm{m}^{2}\right)\end{array}$ & $\begin{array}{l}\text { Proposed } \\
\text { Plate } \\
\text { pack } \\
\text { Quantity } \\
(\mathrm{nos})\end{array}$ & $\begin{array}{l}\text { Total } \\
\text { Surface } \\
\text { area } \\
\text { Provided } \\
\left(\mathrm{m}^{2}\right)\end{array}$ & $\begin{array}{l}\text { Total } \\
\text { plate } \\
\text { pack } \\
\text { quantity } \\
\text { per Area }\end{array}$ \\
\hline 1 & 1 A & R6 & 5,868 & 2 & 2,934 & 586.8 & 306.3 & 2 & 612.6 & 4 \\
2 & 1 B & T7 & 5,508 & 2 & 2,754 & 550.8 & 306.3 & 2 & 612.6 & 4 \\
3 & 1 C & V7 & 9,828 & 2 & 4,914 & 982.8 & 306.3 & 4 & 1225.2 & 8 \\
4 & 1 D & Y6 & 7,740 & 2 & 3,870 & 774 & 306.3 & 3 & 918.9 & 6 \\
5 & 2 A & A6 & 6,480 & 2 & 3,240 & 648 & 306.3 & 3 & 918.9 & 6 \\
6 & 2 B & RR2 & 3.024 & 1 & 3,024 & 604.8 & 306.3 & 2 & 612.6 & 2 \\
7 & 2 C & D9 & 7,380 & 2 & 3,690 & 738 & 306.3 & 3 & 918.9 & 6 \\
8 & 2 D & F7 & 9,900 & 2 & 4,950 & 990 & 306.3 & 4 & 1225.2 & 8 \\
9 & 2 E & I8 & 7,920 & 2 & 3,960 & 792 & 306.3 & 3 & 918.9 & 6 \\
10 & 2 F & I11 & 1,368 & 1 & 1,368 & 273.6 & 306.3 & 1 & 306.3 & 1 \\
& & & TOTAL & 18 & & & & & 5 & 51 \\
\hline
\end{tabular}

Table 9

The optimum quantities of plate packs

\begin{tabular}{lllllllllll}
\hline No & Area & Ref. & $\begin{array}{l}\text { Flow } \\
\text { rate } \\
\left(\mathrm{m}^{3} / \mathrm{h}\right)\end{array}$ & $\begin{array}{l}\text { No of } \\
\text { CPI }\end{array}$ & $\begin{array}{l}\text { Flow } \\
\text { rate @ } \\
\text { each } \\
\text { CPI } \\
\left(\mathrm{m}^{3} / \mathrm{h}\right)\end{array}$ & $\begin{array}{l}\text { Surface } \\
\text { area } \\
\text { required } \\
\left(\mathrm{m}^{2}\right)\end{array}$ & $\begin{array}{l}\text { Plate } \\
\text { Pack } \\
\text { Surface } \\
\text { area }\left(\mathrm{m}^{2}\right)\end{array}$ & $\begin{array}{l}\text { Proposed } \\
\text { Plate } \\
\text { pack } \\
\text { Quantity } \\
(\text { nos.) }\end{array}$ & $\begin{array}{l}\text { Total } \\
\text { Surface } \\
\text { area } \\
\text { Provided } \\
\left(\mathrm{m}^{2}\right)\end{array}$ & $\begin{array}{l}\text { Total } \\
\text { plate } \\
\text { pack } \\
\text { quantity } \\
\text { per Area }\end{array}$ \\
\hline 1 & 1 A & R6 & 5,868 & 2 & 2,934 & 586.8 & 306.3 & 3 & 918.9 & 6 \\
2 & 1 B & T7 & 5,508 & 2 & 2,754 & 550.8 & 306.3 & 3 & 918.9 & 6 \\
3 & 1 C & V7 & 9,828 & 2 & 4,914 & 982.8 & 306.3 & 4 & 1225.2 & 8 \\
4 & 1 D & Y6 & 7,740 & 2 & 3,870 & 774 & 306.3 & 3 & 918.9 & 6 \\
5 & 2 A & A6 & 6,480 & 2 & 3,240 & 648 & 306.3 & 3 & 918.9 & 6 \\
6 & 2 B & RR2 & 3.024 & 1 & 3,024 & 604.8 & 306.3 & 3 & 918.9 & 6 \\
7 & 2 C & D9 & 7,380 & 2 & 3,690 & 738 & 306.3 & 3 & 918.9 & 6 \\
8 & 2 D & F7 & 9,900 & 2 & 4,950 & 990 & 306.3 & 4 & 1225.2 & 8 \\
9 & 2 E & I8 & 7,920 & 2 & 3,960 & 792 & 306.3 & 4 & 1225.2 & 8 \\
10 & 2 F & I11 & 1,368 & 1 & 1,368 & 273.6 & 306.3 & 2 & 612.6 & 2 \\
\hline
\end{tabular}

Both the minimal and the optimal plate pack quantities were re-computed to confirm the results on the actual rise rates and the actual oil globules sizes that can be separated. These results obtained are as shown in Table 10. The results showed that both the minimal and the optimal plate pack quantities were well within the acceptable limits of the design criteria. However, the optimum quantities were giving much more superior results than the required design criteria. Therefore, the optimum quantities of plate packs were successfully chosen. In summary, the 10 areas will have 18 CPI's tanks and 59 plate packs. 


\section{Table 10}

The results of the optimum versus minimum quantities of plate packs

\begin{tabular}{|c|c|c|c|c|c|c|c|c|c|c|c|c|}
\hline Area & $\begin{array}{l}\text { Flow } \\
\text { rate } \\
\left(\mathrm{m}^{3} / \mathrm{h}\right)\end{array}$ & $\begin{array}{l}\text { No } \\
\text { of } \\
\text { CPI }\end{array}$ & $\begin{array}{l}\text { Flow } \\
\text { rate @ } \\
\text { each CPI } \\
\left(\mathrm{m}^{3} / \mathrm{h}\right)\end{array}$ & $\begin{array}{l}\text { Required } \\
\text { Surface } \\
\text { area } \\
\text { Design } \\
\left(\mathrm{m}^{2}\right)\end{array}$ & $\begin{array}{l}\text { Actual } \\
\text { Surface } \\
\text { area } \\
\text { Min } \\
\text { Option } \\
\left(\mathrm{m}^{2}\right)\end{array}$ & $\begin{array}{l}\text { Actual } \\
\text { Surface } \\
\text { area } \\
\text { Opt } \\
\text { Option } \\
\left(\mathrm{m}^{2}\right)\end{array}$ & $\begin{array}{l}\text { Required } \\
\text { Surface } \\
\text { Charge } \\
\text { Design } \\
(\mathrm{m} / \mathrm{h})\end{array}$ & $\begin{array}{l}\text { Actual } \\
\text { Surface } \\
\text { charge } \\
\text { Min. } \\
\text { Option } \\
(\mathrm{m} / \mathrm{h})\end{array}$ & $\begin{array}{l}\text { Actual } \\
\text { Surface } \\
\text { charge } \\
\text { Opt. } \\
\text { Option } \\
(\mathrm{m} / \mathrm{h})\end{array}$ & $\begin{array}{l}\text { Required } \\
\text { Globule } \\
\text { Size } \\
\text { Design } \\
(\mu \mathrm{m})\end{array}$ & $\begin{array}{l}\text { Actual } \\
\text { Globule } \\
\text { Size Min } \\
\text { Option } \\
(\mu \mathrm{m})\end{array}$ & $\begin{array}{l}\text { Actual } \\
\text { Globule } \\
\text { Size Opt. } \\
\text { Option } \\
(\mu \mathrm{m})\end{array}$ \\
\hline$\overline{1 A}$ & 5,868 & 2 & 2,934 & 586.8 & 612.6 & 918.9 & 5 & 4.79 & 3.19 & 130 & 128 & 104 \\
\hline $1 \mathrm{~B}$ & 5,508 & 2 & 2,754 & 550.8 & 612.6 & 918.9 & 5 & 4.50 & 3.00 & 130 & 124 & 101 \\
\hline $1 \mathrm{C}$ & 9,828 & 2 & 4,914 & 982.8 & 1225.2 & 1225.2 & 5 & 4.01 & 4.01 & 130 & 117 & 117 \\
\hline $1 \mathrm{D}$ & 7,740 & 2 & 3,870 & 774.0 & 918.9 & 918.9 & 5 & 4.21 & 4.21 & 130 & 120 & 120 \\
\hline $2 \mathrm{~A}$ & 6,480 & 2 & 3,240 & 648.0 & 918.9 & 918.9 & 5 & 3.53 & 3.53 & 130 & 109 & 109 \\
\hline $2 \mathrm{~B}$ & 3.024 & 1 & 3,024 & 604.8 & 612.6 & 918.9 & 5 & 4.94 & 3.29 & 130 & 130 & 106 \\
\hline $2 \mathrm{C}$ & 7,380 & 2 & 3,690 & 738.0 & 918.9 & 918.9 & 5 & 4.02 & 4.02 & 130 & 117 & 117 \\
\hline $2 \mathrm{D}$ & 9,900 & 2 & 4,950 & 990.0 & 1225.2 & 1225.2 & 5 & 4.04 & 4.04 & 130 & 117 & 117 \\
\hline $2 \mathrm{E}$ & 7,920 & 2 & 3,960 & 792.0 & 918.9 & 1225.2 & 5 & 4.31 & 3.23 & 130 & 121 & 105 \\
\hline $2 \mathrm{~F}$ & 1,368 & 1 & 1,368 & 273.6 & 306.3 & 612.6 & 5 & 2.23 & 2.23 & 130 & 123 & 87 \\
\hline
\end{tabular}

\section{Conclusions}

The introduction of $\mathrm{CPI}$ into the stormwater treatment system located in the airport is quite significant since the airport is known for its large and paved areas that contain oil, grease or jet fuel. Therefore, treating the airport stormwater contaminated with oil, grease or jet fuel could significantly reduce the contamination issue for a better airport environment in Malaysia. The CPI can be fitted to surface water drainage systems to protect the environment from oil pollution. This system separates the oils from the water and then retains the oils safely until it is removed. Additionally, this system is commonly installed to contain oil leaks from vehicles, plants, or accidental spillages. Moreover, the oil separators need to be correctly designed, installed, and maintained to achieve maximal efficiency. The performance of CPI is based on the inlet design criteria of $4250 \mathrm{mg} / \mathrm{l}$ oil content and is expected to meet the $5 \mathrm{mg} / \mathrm{l}$ of oil at the outlet, in accordance with the BSEN858-1 \& 2 requirements. Although these inlet and outlet design criteria are in accordance with international standards, as well as are expected to follow very high and stringent standards, but the actual inlet condition can only be verified if an actual wastewater characteristic study is done at the inlet at each proposed location.

\section{Acknowledgement}

The authors would like to express their gratitude to the Ministry of Education, Malaysia, for funding this research under the MyBrain $15 \mathrm{PhD}$ Industry Scholarship Grant. This research also was partially funded by Universiti Teknologi Malaysia under the UTM Prototype Research grant; Vote Number: Q.K130000.2856.00L57.

\section{References}

[1] Åsteb $\varnothing l$, Svein Ole, Thorkild Hvitved-Jacobsen, and $\varnothing$ yvind Simonsen. "Sustainable stormwater management at Fornebu-from an airport to an industrial and residential area of the city of Oslo, Norway." Science of the total environment 334 (2004): 239-249. https://doi.org/10.1016/i.scitotenv.2004.04.042

[2] Nunes, L. M., Y-G. Zhu, T. Y. Stigter, José Paulo Monteiro, and M. R. Teixeira. "Environmental impacts on soil and groundwater at airports: origin, contaminants of concern and environmental risks." Journal of Environmental Monitoring 13, no. 11 (2011): 3026-3039. https://doi.org/10.1039/c1em10458f

[3] Sulej-Suchomska, Anna Maria, Żaneta Polkowska, Zenon Józef Kokot, Miguel de La Guardia, and Jacek Namieśnik. "Determination of antifreeze substances in the airport runoff waters by solid-phase microextraction and gas 
chromatography-mass spectrometry method." Microchemical Journal $126 \quad$ (2016): $466-473$. https://doi.org/10.1016/i.microc.2016.01.003

[4] de Castro Carvalho, Isabella, Maria Lúcia Calijuri, Paula Peixoto Assemany, Marcos Dornelas Freitas Machado e Silva, Ronan Fernandes Moreira Neto, Aníbal da Fonseca Santiago, and Mauro Henrique Batalha de Souza. "Sustainable airport environments: A review of water conservation practices in airports." Resources, Conservation and Recycling 74 (2013): 27-36. https://doi.org/10.1016/i.resconrec.2013.02.016

[5] Odiete, William E., and Jonah C. Agunwamba. "Novel design methods for conventional oil-water separators." Heliyon 5, no. 5 (2019): e01620. https://doi.org/10.1016/i.heliyon.2019.e01620

[6] Zeng, Quanshu, Zhiming Wang, Xiaoqiu Wang, Yanlong Zhao, and Xiao Guo. "A novel oil-water separator design and its performance prediction." Journal of Petroleum Science and Engineering 145 (2016): 83-94. https://doi.org/10.1016/i.petrol.2016.03.015

[7] Zhang, Lianbin, Yujiang Zhong, Dongkyu Cha, and Peng Wang. "A self-cleaning underwater superoleophobic mesh for oil-water separation." Scientific reports 3, no. 1 (2013): 1-5. https://doi.org/10.1038/srep02326

[8] Han, Yunrui, Limin He, Xiaoming Luo, Yuling Lü, Kaiyue Shi, Jianheng Chen, and Xin Huang. "A review of the recent advances in design of corrugated plate packs applied for oil-water separation." Journal of industrial and engineering chemistry 53 (2017): 37-50. https://doi.org/10.1016/i.jiec.2017.04.029

[9] Chen, Bowen, Bo Wang, Feng Mao, Bingzheng Ke, Jiming Wen, Ruifeng Tian, and Chuan Lu. "Review on separation mechanism of corrugated plate separator." Annals of Nuclear Energy 144 (2020): 107548. https://doi.org/10.1016/i.anucene.2020.107548

[10] Le, Thuy Thi, Son Ich Ngo, Young-II Lim, Chi-Kyun Park, Byung-Don Lee, Byung-Gook Kim, and Dong-Ha Lim. "Threephase Eulerian computational fluid dynamics of air-water-oil separator under off-shore operation." Journal of Petroleum Science and Engineering 171 (2018): 731-747. https://doi.org/10.1016/i.petrol.2018.08.001

[11] Boraey, Mohammed A. "A hydro-kinematic approach for the design of compact corrugated plate interceptors for the de-oiling of produced water." Chemical Engineering and Processing-Process Intensification 130 (2018): 127133. https://doi.org/10.1016/i.cep.2018.06.006

[12] Jaworski, Artur J., and Guangtian Meng. "On-line measurement of separation dynamics in primary gas/oil/water separators: Challenges and technical solutions-A review." Journal of Petroleum Science and Engineering 68, no. 12 (2009): 47-59. https://doi.org/10.1016/i.petrol.2009.06.007

[13] "Cross Flow Interceptor Technology." n.d. Accessed April 20, 2021. http://www.mec.my/cross-flow-interceptortechnology/

[14] Wang, Ben, Weixin Liang, Zhiguang Guo, and Weimin Liu. "Biomimetic super-lyophobic and super-lyophilic materials applied for oil/water separation: a new strategy beyond nature." Chemical Society Reviews 44, no. 1 (2015): 336-361. https://doi.org/10.1039/C4CS00220B

[15] Dong, Ying, Jing Li, Lei Shi, Xiaobo Wang, Zhiguang Guo, and Weimin Liu. "Underwater superoleophobic graphene oxide coated meshes for the separation of oil and water." Chemical communications 50, no. 42 (2014): 5586-5589. https://doi:10.1039/c4cc01408a

[16] Zhang, Wenbin, Yuzhang Zhu, Xia Liu, Dong Wang, Jingye Li, Lei Jiang, and Jian Jin. "Salt-induced fabrication of superhydrophilic and underwater superoleophobic PAA-g-PVDF membranes for effective separation of oil-in-water emulsions." Angewandte Chemie International Edition 53, no. 3 (2014): 856-860. https://doi.org/10.1002/anie.201308183

[17] Judd, S., H. Qiblawey, M. Al-Marri, C. Clarkin, S. Watson, A. Ahmed, and S. Bach. "The size and performance of offshore produced water oil-removal technologies for reinjection." Separation and purification technology 134 (2014): 241-246. https://doi.org/10.1016/i.seppur.2014.07.037

[18] Yayla, Sedat, Soran Sabah Ibrahim, and Ali Bahadır Olcay. "Numerical investigation of coalescing plate system to understand the separation of water and oil in water treatment plant of petroleum industry." Engineering Applications of Computational Fluid Mechanics 11, no. $1 \quad$ (2017): $184-192$. https://doi.org/10.1080/19942060.2016.1273137

[19] Wang, Xiaojing, Yangyang Yan, and Zhongzheng Xu. "Application experiment and numerical simulation analysis of oil-water separator with two-oriented corrugated coalescence plate." Journal of Dispersion Science and Technology 38, no. 10 (2017): 1509-1515. https://doi.org/10.1080/01932691.2016.1259072

[20] Ivanenko, A. Yu, M. A. Yablokova, and S. I. Petrov. "Simulation of the separation of emulsified oil products from water in an apparatus with sinusoidal-profiled oleophilic plates." Theoretical Foundations of Chemical Engineering 44, no. 5 (2010): 729-741. https://doi.org/10.1134/S0040579510050143

[21] British Standards Institution, BSEN 858-1 (2002). Separator Systems for Light Liquids (E.g., Oil and Petrol). Principles of Product Design, Performance and Testing, Marking and Quality Control. British Standards Institution, London, UK. n.d. 
[22] American Petroleum Institute (API) (1990). Monographs on Refinery Environmental Control-Management of Water Discharges Design and Operations of Oil-Water Separators. First Edition, API Publication 421, USA. n.d.

[23] British Standards Institution, BSEN 858-2 (2003). Separator Systems for Light Liquids (E.g., Oil and Petrol). Selection of Nominal Size, Installation, Operation and Maintenance. British Standards Institution, London, UK. n.d.

[24] Department of Environment (DOE) (2010). Environmental Quality Act 1974 -Environmental Quality (Industrial Effluent) Regulations 2009. Ministry of Natural Resources and Energy, Malaysia. 